\title{
Ownership of The Archery Based on Legal Policy in Indonesia
}

\author{
Tahegga Primananda Alfath ${ }^{1}$, Dellie Threesyadinda ${ }^{2}$ \\ \{ tahegga.primananda@narotama.ac.id ${ }^{1}$, \} \\ Universitas Narotama, Surabaya, Indonesia ${ }^{1,2}$
}

\begin{abstract}
Legal Arrangements regarding Archery Equipment Ownership have not been clearly regulated in Indonesian laws and regulations, the potential danger can be caused by misuse of archery equipment that resembles sharp weapons. This research aims to determine whether or not the Archery Equipment is meticulous in the elements of sharp weapons in Emergency Law Number 12 of 1951 and to find out the legal rules that are in accordance with the Indonesian legal system that can regulate ownership of the Archery Equipment. In order to achieve this goal, this legal research uses a legislative approach and a conceptual approach. Where the legislative approach is carried out by examining all legislation relating to this research, and the conceptual approach is carried out by referring to legal principles found in concepts, legal doctrines, so that they can be used as a basis for establishing an argument law in solving the issues at hand. The results of this study found that (1) Archery equipment meets the elements of sharp weapons, (2) The National Police of the Republic of Indonesia as the party that has the authority to supervise and control can make rules regarding the Arrangement of Archery Equipment issued in the form of Regulations National Police Chief.
\end{abstract}

Keywords: Archery, Regulation, Sharp weapons.

\section{Introduction}

Archery is an activity using arrows to shoot arrows. Archery is one of the oldest sports in the world, but no one knows for sure when the bow and arrow are found for the first time. Since the prehistoric era, both of these tools have been used for hunting and protecting themselves from enemy attacks. History proves that the use of arcs and arrows can be seen as a relic in prehistoric times, estimated to be around 50,000 years ago. One proof of inheritance is paintings or hunting pictures of animals found in caves. Of course, at that time archery equipment was still very simple. Recently the Archery sport caught the attention of the public, which at first was very minimal, and then developed. But in this case what interests the author is a sport that has elements resembling Archery sports, namely Shooting sports. Both Archery and Shooting sports can only be held in places specifically designated for this sport, not anywhere. The target area must be sterile, no civilians are allowed around the target area, this is because it can cause accidents in the form of injuries to loss of life.

Potential dangers that can be caused by sports equipment, where in this case, the function of the tool as a sporting tool turns into a tool that can be categorized as causing death. Firearms, which are one of the types of equipment used in firing, are also included in the classification of defense and security weapons used by competent state apparatus such as the Indonesian National Police and the Indonesian National Army. Along with the times, there has been 
abuse of firearms by civil society, one example of which is an action that refers to terrorism. Abuse of weapons not only on firearms, but there are also cases of abuse of archery equipment so that it was realized the need for a legal umbrella regulating as an effort to prevent abuse of archery equipment.

\section{Research Method}

Legal research methods used examining library materials or secondary data to identify concepts and principles and the principles of the problems discussed in writing to find the truth of coherence, namely whether there are legal rules according to legal norms and are there norms in the form of orders or the ban was in accordance with the legal principles, as well as whether the act (act) a person in accordance with legal norms. The approach used in this paper is the approach of legislation (statute approach) and the conceptual approach (conceptual approach). The statute approach is an approach using legislation and regulation. This approach is carried out by examining all legislation, both legislation, and regulations that have relevance to the formulation of the problem in this study. The conceptual approach is carried out by referring to legal principles that can be found in concepts, legal doctrines. So that it will become a support for researchers in building a legal argument in solving the issues at hand.

\section{Discussion}

\subsection{The Concept of Sharp Weapons in Laws and Regulations in Indonesia}

In Indonesian legislation, there are no rules that specifically regulate sharp weapons. However, regarding sharp weapons is generally regulated in several laws. The first, in Law Number 2 of 2002 concerning the National Police of the Republic of Indonesia in Article 15 paragraph (2) letter (e) which explains that the National Police of the Republic of Indonesia has the authority to give permission and supervise firearms, explosives and sharp weapons[1]. The second, in Emergency Law No. 12 of 1951 concerning Firearms changed "ordonnantietijdelijke bijzondere strafbepalingen" (stbl. 1948 number 17) [2] and the Law of the Republic of Indonesia in the past number 8 in 1948, in article 2 number (1) [3]reads:

"Anyone who has no right enters Indonesia, creating, receiving, trying to get it, hand over or try to submit, dominate, carry, or have had a stockpile him in hers, storing, transporting, concealing, use or release of Indonesian something beater arms, weaponsthruster,or weapons awl (slag-,steek -, of Stootwapen), punished with a maximum prison sentence of ten years. "

Based on Dictionary, the definition of stabber comes from the basic word stab, which means puncture using sharp objects, such as a dagger or spear with wider translation, namely piercing each other with weapons sharp. So based on this, it can be concluded that there are similarities in meaning between piercing weapons, piercers belonging to the type of sharp weapon.

The definition of sharp weapons contained in legislation in Indonesi will be found in Article 15 paragraph (2) letter (e) of Law Number 2 Year 2002 concerning Police, which states[1]: 
"what is meant by sharp weapons in this Law is weapons sharp piercing, sharp piercing weapons, and battering weapons, not including items that are obviously used for agriculture, for domestic workers, for the purpose of doing legitimate or real work, for the purpose of inheritance, ancient goods, magic goods as regulated in Law Number 12/Drt/1951. In addition, the understanding of weapons is a tool that is useful for fighting or fighting. "

Another understanding of sharp weapons can also be found in Emergency Law No. 12 of 1951 concerning Firearms changed "ordonnantietijdelijke bijzondere strafbepalingen" (stbl. 1948 number 17) [2] and the Indonesian republic law number 8 of 1948 contained in article 2 paragraph (2) also stated[3]:

"what is meant by sharp weapons is stabbing weapons, stab guns, and bat weapons not including items that are obviously included for use in agriculture, or domestic work or for the purpose of legitimately carrying out work or actually having a purpose as inheritance or antiquity or magic items (merkwaardigheid )."

\subsection{Elements of Sharp Weapons}

In the formulation of the provisions contained in Emergency Law Number 12 of $1951 \mathrm{Ar}$ ticle 2 Paragraph (1) states that criminal sanctions in the form of prison sentences are a form of deterrent and preventive effects and security from the government against abuse sharp weapons which are described as beating weapons, stab guns or piercing[2]. Sanctions are imposed if a person who has no right to enter Indonesia, makes, accepts, tries, obtains, submits, or attempts to assert, control, carry, possess to him or possess in his possession, store, transport, hide, use or remove from Indonesia something bat, stab weapon, or weapon (stabs lag, steak of stoat weapon).

\subsection{Concepts Archery}

Equipment used in archer, among others: bow and arrow, which consists of several components in it as follows:

1. Bows: handle, upper limb, lower limb, bow string, slighter, place the back of the arrow (arrow rest)

2. Arrow: Bedor (arrow metal point), axle (shaft), fletching, Arrow tail ( nock).

Based on the description of the anatomy of the arrow, then on the arrow there is a bedor/arrow head point, which is one of the parts made of metal and has sharpness so that this makes the sharpness in the tool arrow. The bow has a function as a pulling device whose purpose is to shoot arrows to stick to the target so that it can be said that the arrow has the essence of sharpness in the arrows including sharp weapons.

\subsection{Coherence of Archery as Sharp Weapons Prohibited by Legislation.}

Regarding the description of the arrow tool parts, the conclusion is obtained that in the part of Bedor the arrow, it has the essence of sharpness. Where the sharpness meets the elements of the piercing weapon which in other words means sharp weapons. On the other hand, the material and the results of the formation of arrowheads are intended to hit the target when the arrow is released, sticking to the target. This is enough to prove, that the arrow bedor has a 
sharpness that can be used as a weapon, the same thing if it is an analogy with firearms or other types of firearms.

But in Indonesian laws and regulations, weapons that are used for sports are certainly not prohibited. This can be analogous to the Regulation of the Head of the Republic of Indonesia National Police Number 8 of 2012 concerning the Control and Control of Firearms for Sports in the Weighing Section of Police Regulation Number 8 of 2012 that firearms for sporting purposes are needed to support shooting sports achievements, and the National Police of the Republic of Indonesia is obliged to carry out administrative and physical supervision and control over the ownership and use of sports firearms.

Regulations regarding shooting equipment are arranged in such a way, however, not so with archery. Archery has the same analogy with an airsoft gun, which is a sporting equipment that has a function as a weapon and meets the element of sharp weapons in its arrow parts so that it can cause abuse that is prohibited by law and even endanger the security and defense of the Republic of Indonesia, for example using arrow tools for acts of harm to other people, officials, and acts of terrorism.

In the formulation of the provisions contained in Emergency Law Number 12 of $1951 \mathrm{Ar}-$ ticle 2 Paragraph (1) states that criminal sanctions in the form of prison sentences are a form of deterrent and preventive effects as well as government safeguards against misuse of sharp weapons which are described as beating weapons, stabbing weapons or weapons awl. Sanctions are imposed if a person who has no right to enter Indonesia, makes, accepts, tries, obtains, submits, or attempts to assert, control, carry, possess to him or possess in his possession, store, transport, hide, use or remove from Indonesia something bat, stab weapon, or weapon (stabs lag, steak of stoat weapon).

The application of the law regarding sharp weapons ownership and abuse of sharp weapons is already in the decision number 2062/Pid.B/2016/PN.Mks. The judge ruled that the defendant Muhammad Asri Pratama Bin Asrul was found guilty of committing a criminal act of carrying or possessing a sharp weapon without permission and imposing a prison sentence for 9 (nine) months by specifying the duration of detention that the defendant had taken was entirely deducted from the sentence. The judge also ordered the defendant to remain in detention while undergoing a criminal prison process. And stipulates evidence in the form of 1 (one) sharp weapon of arrow type made of iron at the tip and pointed.

\subsection{Legal Policy In Accordance of The Ownership Of Archery In Indonesia}

Rules regarding sharp weapons, in general, are made by the government through the legal rules of Emergency Law Number 12 of 1951 in accordance with the constitutional basis stated in the opening of the 1945 Constitution of the Republic of Indonesia. 1945 has the connection that the legitimacy of the 1945 Constitution of the Republic of Indonesia as the Constitution of the State and the source of all legal sources of legislation in Indonesia[4].

In Article 8 Paragraph (1) of Law Number 12 of 2011 concerning the Establishment of Legislation Regulations governed by the type of Legislation as referred to in Article 7 Paragraph (1) is recognized and has binding legal force insofar as it has been regulated by Higher legislation or established based on the authority of state institutions, the regulations issued will be legally recognized.

Arrangements regarding sharp weapons in Law Number 2 of 2002 concerning the National Police of the Republic of Indonesia in Article 15 paragraph (2) providing understanding of sharp weapons are stabbing weapons, stab guns and beating weapons, excluding items that are clearly used for domestic work, or for the purpose of doing a legitimate, or real work for the 
purpose of inheritance or ancient goods, or magic goods as stipulated in the previous rules, namely in Emergency Law No. 12 of 1951. The regulation in Emergency Law Number 12 of 1951 is also so, referring to the Opening section of the 1945 Constitution of the Republic of Indonesia that the Government of Indonesia will protect all Indonesian people, Emergency Law issued by the President or Government when the State emergency and force, in which the force is made an Emergency Law for the benefit of the safety of all the people of Indonesia. For the implementation of Law Number 2 of 2002, that the National Police of the Republic of Indonesia as an institution authorized to supervise and control sharp weapons, this refers to Article 30 of the 1945 Constitution of the Republic of Indonesia as the highest source of law in Indonesia, explained in Article 30 Paragraph (4) that the National Police of the Republic of Indonesia as a state instrument that maintains security and public order has the duty to protect, protect, serve the community, and uphold the law.

\section{Conclusion}

The rules that regulate special procedures for Archery Tools do not yet exist in Indonesia, so a strong legal umbrella is needed to protect state security, in conclusion the first problem can be concluded that arrows meet elements of sharp weapons, but archery tools are also sports equipment, so the appropriate legal rules regarding Ownership of Archery Tools can be adopted from the Regulation the Chief of Police Number 8 of 2012 concerning Control and Control of Firearms for Sports Purposes. The National Police of the Republic of Indonesia as the authorized party to supervise and control administratively and physically the ownership and use of sports weapons as well as the authorities to issue the issuance of licenses, supervision, and control of weapons, both firearms and sharp weapons. And also in Law Number 2 of 2002, that the National Police of the Republic of Indonesia as an institution authorized to supervise and control sharp weapons, this refers to Article 30 of the 1945 Constitution of the Republic of Indonesia as the highest source of law in Indonesia, explained in Article 30 Paragraph (4) that the National Police of the Republic of Indonesia as a state instrument that maintains security and public order has the duty to protect, protect, serve the community, and uphold the law

\section{References}

[1] Presiden Republik Indonesia, "Undang-Undang Republik Indonesia Nomor 2 Tahun 2002 Tentang Kepolisian Negara Republik Indonesia,” Jakarta, 2002.

[2] Presiden Republik Indonesia, "Undang-Undang Darurat Republik Indonesia Nomor 12 Tahun 1951 Tentang Mengubah 'Ordonnantietijdelijke Bijzondere Strafbepalingen' (stbl. 1948 Nomor 17) Dan Undang-Undang Republik Indonesia Dahulu Nomor 8 Tahun 1948 Presiden,” Jakarta, 1951.

[3] Presiden Republik Indonesia, "Undang-Undang Republik Indonesia Nomor 8 Tahun 1948 Senjata Api. Pendaftaran Idzin Pemakaian. Mencabut Peraturan Dewan Pertahanan Negara No. 14 dan menetapkan Peraturan tentang Pendaftaran Dan Pemberian Idzin Pemakaian Senjata Api.," Jakarta, 1948

[4] Indonesia, “Undang-Undang Dasar Negara Republik Indonesia Tahun 1945,” 1945. 